\title{
TINJAUAN SOSIOLOGI HUKUM TERHADAP ZAKAT SEBAGAI PENGURANG PENGHASILAN PAJAK UU NO. 23 TAHUN 2011 PASAL 22 ( STUDI ANALISIS PENDEKATAN USHUL FIKIH)
}

\author{
Rafik Patrajaya
}

IAIN Palangka Raya, Central Kalimantan, Indonesia

rafikpatrajaya@gmail.com

Received:03-03-2019; Revised:13-05-2019; Accepted: 18-05-2019

\section{ABSTRACT}

As one of the important themes in the management of zakat, the government has approved and stipulated zakat as a deduction from Taxable Income. Furthermore, this policy does not only cover zakat, but also compulsory religious contributions, which means the BAZNAS struggle for tax reduction, is also enjoyed by other religious adherents. The amount of zakat and donations that can be calculated as a deduction from income is 2.5\%. This is in accordance with Law No. 23 of 2011 article 22 which is an amendment to Law No. 38 of 1999. This paper tries to describe the analysis of the concept of Zakat Management which is reviewed in the perspective of legal sociology with the method of normative-sociological approaches and the study of ushul fiqh. In a review of the legal sociology of zakat as a tax deduction seen from its implementation it will have an effect on the tax sector, because it reduces tax revenues. As for the review of ushul fiqh related to Law No. 23 of 2011 concerning Management of Zakat, that the government here has made reform efforts in regulating the issue of zakat law in order to prosper the welfare of its people, and this is enough to represent the intent of maqasid ash-Sharia in achieving the goal of benefit both in the world and benefit in the hereafter. In Islam, it is not possible to replace the position of zakat with taxes. What is possible is integrating, among others, by cutting the amount of tax with the amount of zakat paid by someone. this method may be acceptable because according to their belief they have fulfilled religious obligations along with fulfilling their obligations to the State.

Keywords: Sociology of Law, UU No. 23 Tahun 2011 about Zakat, Ushul Fiqh

\section{INTISARI}

Sebagai salah satu tema penting dalam pengelolaan zakat, pemerintah telah menyetujui dan menetapkan zakat sebagai pengurang dari Penghasilan Kena Pajak. Selanjutnya kebijakan ini tidak hanya mencakup zakat saja tetapi juga sumbangan keagamaaan yang bersifat wajib artinya perjuangan BAZNAS untuk pengurangan pajak, juga dinikmati oleh para pemeluk agama yang lain. Besarnya zakat dan donasi yang bisa diperhitungkan sebagai pengurang penghasilan adalah sebesar 2,5\%. Hal ini sesuai dengan UU No. 23 tahun 2011 pasal 22 yang merupakan amandemen dari UU No. 38 tahun 1999. Tulisan ini mencoba mendeskripsikan analisis tentang konsep Pengelolaan Zakat yang ditinjau dalam perspektif sosiologi hukum dengan metode pendekatan normatif-sosiologis dan kajian ushul fikih. Dalam tinjauan sosiologi hukum zakat sebagai pengurang pajak dilihat dari implementasinya akan berpengaruh dalam sektor pajak, karena mengurangi pendapatan pajak. Adapun dalam tinjauan ushul fikihnya terkait dengan 
Undang-Undang No. 23 Tahun 2011 tentang Pengelolaan Zakat, bahwa pemerintah di sini sudah melakukan upaya-upaya pembaruan dalam mengatur masalah UU zakat demi memakmurkan kesejahteraan masyarakatnya, dan ini sudah cukup mewakili maksud dari maqasid asy-Syariah dalam mencapai tujuan kemaslahatan baik di dunia maupun kemaslahatan di akhirat. Dalam Islam, tidaklah mungkin menggantikan kedudukan zakat dengan pajak. Yang mungkin adalah memadukannya, antara lain dengan memotong jumlah pajak dengan jumlah zakat yang telah dibayar oleh seseorang. cara ini mungkin akan dapat diterima Karena menurut keyakinan mereka kewajiban agama telah mereka penuhi bersamaan dengan pemenuhan kewajibannya terhadap Negara.

Kata Kunci: Sosiologi Hukum, UU No. 23 Tahun 2011 tentang Zakat, Ushul Fiqh

\section{A. Pendahuluan}

Islam merupakan agama terakhir yang diturunkan oleh Allah Swt kepada umat manusia lewat Nabi terakhir Muhammad Saw. Sebagai agama terakhir, Islam memiliki berbagai aturan dan tata laksana yang harus dilaksanakan oleh umatnya, baik yang sifatnya "melanjutkan" ajaran sebelumnya atau "membuat" ajaran baru. Salah satu ajaran Islam yang sifatnya "melanjutkan" tersebut adalah ibadah zakat. Namun demikan, zakat, mempunyai posisi penting dalam Islam, bahkan zakat ini merupakan salah satu dari rukun Islam, di samping shalat, puasa, dan haji. Zakat bukanlah syariat baru yang hanya terdapat pada syariat Islam yang dibawa oleh Nabi Muhammad saw. Akan tetapi, zakat juga merupakan bagian dari syariat yang dibawa oleh para Rasul terdahulu. Karena itu, dapat dikatakan bahwa zakat sebagai ibadah yang menyangkut harta benda dan berfungsi social itu telah "berumur tua" karena telah dikenal dan diterapkan dalam agama samawi yang dibawa oleh para Rasul terdahulu. ${ }^{1}$

Meskipun merupakan kewajiban ibadah kepada Allah Swt, zakat belum dikumpulkan dan didistribusikan melalui lembaga formal selama masa awal di Makkah karena jumlah kaum muslimin ketika itu relatif masih sedikit dan hidup dalam masyarakat yang memusuhi keyakinan mereka. Kaum muslimin mengeluarkan zakat secara pribadi untuk membantu orang-orang miskin dan untuk menebus kemerdekaan mereka yang dijadikan budak. ${ }^{2}$ Menurut Yusuf al-Qardhawi bahwa zakat yang disebutkan dalam al-Qur'an al-Makky masih bersifat umum, tanpa kekhususan atau peraturan. Pembayaran zakat pada masa itu tergantung pada kesadaran masing-masing atau rasa kedermawanannya, dan rasa kewajiban untuk membantu sesama mukmin. ${ }^{3}$

Sesuai dengan amanat Allah di dalam al-Qur'an dan fungsi Undang-undang nomor 38 tahun 1999 tentang Pengelolaan Zakat dan Keputusan Menteri Agama (KMA) Republik Indonesia Nomor 38 tahun 1999 Tentang Pengelolaan Zakat serta Keputusan Direktor Jenderal Bimbingan Masyarakat Islam dan Urusan Haji Nomor D/291 tahun 2000 Tentang Pedoman Teknis Pengelolaan Zakat bahwa pengelolaan zakat merupakan bagian integral dari proses pembentukan dan penguatan Ekonomi Islam secara makro. Untuk itu penunaian zakat bukan hanya sebatas menggugurkan kewajiban, tetapi bagaimana pembayaran dana

\footnotetext{
${ }^{1}$ Fakhruddin, Fiqh \& Manajemen Zakat di Indonesia, (UIN-Malang Press: 2008), hlm. 1-2.

${ }^{2}$ Abdallah al-Sheiekh dalam John E. Efosito, Ensiklopedi Dunia Islam Modern, Jilid 6, (Jakarta: Mizan, 2001), hlm. 185.

${ }^{3}$ Yusuf al-Qardhawi, Figh al-Zakah, Muassasah al-Risalah, (Beirut: Dar al-Fikr, t.t.,), hlm. 61.
} 
zakat dapat berhasil guna dan berdaya guna bagi kepentingan masyarakat. Zakat bukan hanya membersihkan jiwa dan harta, tetapi juga zakat dapat berperan aktif mengentaskan dan membersihkan penyakit-penyakit sosial, seperti: kemiskinan, kebodohan, dan lain-lain. Zakat juga dapat diarahkan kepada upaya peningkatan sumber daya manusia (SDM). ${ }^{4}$

Pemerintah telah menyetujui dan menetapkan Zakat sebagai pengurang dari Penghasilan Kena Pajak. Selanjutnya kebijakan ini tidak hanya mencakup zakat saja tetapi juga sumbangan keagamaaan yang bersifat wajib artinya perjuangan BAZNAS untuk pengurangan pajak, juga dinikmati oleh para pemeluk agama yang lain. Besarnya zakat dan donasi yang bisa diperhitungkan sebagai pengurang penghasilan adalah sebesar 2,5\%. Hal ini sesuai dengan UU no 38 tahun 1999 pasal 14 (3) tentang pengelolaan zakat dan UU No. 23 tahun 2011 pasal 22 yang merupakan amandemen dari UU No. 38 tahun 1999. Dalam pembahasan penlitian ini, penulis akan mencoba membahas tentang zakat yang merupakan hasil pengurangan dari pajak penghasilan ditinjau dari sosiologi hukum dengan menggunakan metode kajian analisis ushul fikih. Dengan melihat permasalahan di atas, maka dapatlah diambil suatu rumusan masalah yang akan dibahas pada penelitian yaitu, Bagaimanakah tinjauan sosiologi hukum terhadap Undang-undang zakat tersebut apakah sudah cukup refresentatif serta bagaimana dalam perspektif ushul fikih mengkajinya mengenai zakat.

\section{B. Metode Penelitian}

Jenis penelitian ini menggunakan studi pustaka (Library Research), yang termasuk ke dalam penelitian normatif. ${ }^{5}$ Adapun sumber penelitian ini terbagi ke dalam tiga bahan, yakni primer, sekunder dan tersier. Bahan primer meliputi Undang-undang Zakat No. 23 Tahun 2011, selaian bahan premir tersebut digunakan pula bahan pendukung yang lain yaitu sekunder dan tersier yang terkait bahan kajian buku-buku hukum atau jurnal tentang masalah zakat. Metode yang digunakan dalam penelitian ini adalah deskriptif kualitatif dengan pendekatan normatifsosiologis dan kajian ushul fiqh.

\section{Pembahasan}

\section{Konsep Zakat dan Dasar Hukum}

Zakat adalah ibadah yang berkaitan dengan harta benda yang telah disepakati (maaliyyah ijtima'iyyah) yang memiliki posisi strategis, dan menentukan, baik dilihat dari sisi ajaran Islam maupun dari sisi pembangunan kesejahteraan umat. Sebagai suatu ibadah pokok, zakat termasuk salah satu rukun ketiga rukun Islam yang lima. Zakat ditinjau dari segi bahasa (lughatan) mempunyai beberapa arti, yaitu keberkahan (al-barkatu), pertumbuhan dan perkembangan, (alnama') kesucian (ath-tharatu) dan keberesan (ash-Shalahu). Sedangkan arti zakat secara istilah (syar'iyyah) ialah bahwa zakat itu merupakan bagian dari harta dengan persyaratan tertentu, yang Allah Swt mewajibkan kepada pemiliknya untuk diserahkan kepada yang berhak menerimanya, dengan persyaratan tertentu pula. ${ }^{6}$

Sahhatih mengungkapkan definisi zakat menurut pendapat empat mazhab sebagai berikut:

\footnotetext{
${ }^{4}$ Mursyid, Mekanisme Pengumpulan Zakat, Infaq dan Shadaqah; Menurut Hukum Syara' dan Undangundang, (Yogyakarta: Magistra Insania Press, 2006), hlm. XV.

5 Soerjono Soekanto dan Sri Mamudji, Penelitian Hukum Normatif, (Jakarta: Raja Grafindo Persada, 2003), hlm. 13 .

${ }^{6}$ Ismail Nawawi, Zakat dalam Perspektif Fiqh, Sosial \& Ekonomi, (Surabaya: CV. Putra Media Nusantara, 2010), hlm. 1.
} 
a. Definisi zakat menurut mazhab Hanafi

Menurut fuqaha mazhab Hanafi mal adalah pemberian karena Allah, agar dimiliki oleh orang fakir yang beragama Islam, selaian Bani Hasyim dan bekas budaknya, dengan ketentuan bahwa manfaat harta itu harus terputus, yakni tidak mengalir lagi pada pemiliknya yang asli dengan cara apapun.

b. Menurut Mazhab Maliki

Zakat dalam pendapat para fuqaha Maliki, bahwa zakat mal ialah mengeluarkan bagian tertentu dari harta tertentu pula, yang telah mencapai nisab diberikan kepada yang berhak menerimanya, yakni bila barang itu milik penuh dari pemberian dan telah berulang tahun, untuk selain barang tambang dan hasil pertanian.

c. Menurut Mazhab Syafi'i

Para fuqaha Syafi'I mengatakan zakat mal ialah harta tertentu yang dikeluarkan dari harta tertentu dengan cara tertentu pula. Menurut mereka zakat mal itu ada dua macam. Pertama berkaitan dengan nilai, yaitu zakat dagang dan, kedua berkaitan dengan barang itu sendiri. Zakat jenis ini ada tiga macam, yaitu binatang, barang berharga, dan tanaman.

d. Menurut Mazhab Hambali

Menurut para fuqaha Hamabali zakat ialah hak yang wajib dikeluarkan dari suatu harta. Kemudian sebelum mempelajari dan membahas cirri-ciri zakat mal sebagai suatu hak tertentu dalam harta, kami nyatakan di sini bahwa prinsipnya memungut dan membagikan zakat mal merupakan tugas pemerintah dalam suatu Negara. Dengan kata lain, menurut bahasa hukum zakat termasuk kekayaan rakyat yang diatur oleh pemerintah. ${ }^{7}$

Pernyataan ini dimaksudkan agar tidak ada pengertian bahwa zakat merupakan kebaikan hati si pemberi secara pribadi. Hal itu karena zakat sama sekali tidak didasarkan kehendak pribadi dalam arti, boleh dilaksanakan dan juga boleh tidak, kecuali bila terpaksa ketika baitul mal kosong umpamanya. Padahal sebenarnya tidak demikian.

Adapun dalam pasal 1 angka 2 Undang-undang zakat No. 23 Tahun 2011 tentang Pengelolaan Zakat disebutkan bahwa zakat adalah harta yang wajib dikeluarkan oleh seorang muslim atau badan usaha untuk diberikan kepada yang berhak menerimanya sesuai dengan syariat Islam. ${ }^{8}$ Adapun sebelum amandemen tentang pengelolaan zakat yang tertuang dalam pasal 1 angka 2 Undang-Undang No. 38 Tahun 1999 tentang Pengelolaan Zakat disebutkan bahwa zakat adalah harta yang wajib disisihkan oleh seorang muslim atau badan yang dimiliki oleh seorang muslim sesuai dengan ketentuan agama untuk diberikan kepada yang berhak menerimanya. ${ }^{9}$ Kemudian pengelolaan zakat itu sendiri dalam pasal 1 angka 1 diartikan sebagai kegiatan perencanaan, pengorganisasian, pelaksanaan, dan pengawasan terhadap pengumpulan dan pendistribusian serta pendayagunaan zakat. ${ }^{10}$

Adapun dasar hukum zakat ini terdapat dalam al-Qur'an, Hadis dan Ijtihad para ulama, sebagai berikut:

a. Al-Qur'an

\footnotetext{
${ }^{7}$ Ibid., hlm. 1-3.

${ }^{8}$ Undang-Undang No. 23 Tahun 2011 Tentang Pengelolaan Zakat.

${ }^{9}$ Undang-Undang No. 38 Tahun 1999 Tentang Pengelolaan Zakat.

10 Abdul Ghofur Anshori dan Yulkarnain Harahab, Hukum Islam Dinamika dan Perkembangannya di Indonesia, (Yogyakarta: Kreasi Total Media, 2008), hlm. 243-244.
} 
Ketentuan dalam al-Qur'an yang menjadi dasar hukum mengenai kewajiban membayar zakat pada setiap muslim terdapat dalam beberapa surat. Di antaranya adalah dalam surah al-Baqarah: $43,{ }^{11}$ al-An'am: $141 .^{12}$

b. Hadis

Ketentuan hadis Nabi Muhammad SAW yang menjadi dasar hukum bagi kewajiban membayar zakat bagi setiap muslim antara lain yaitu:

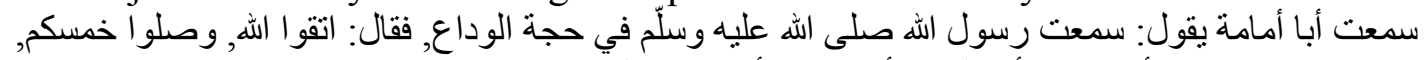

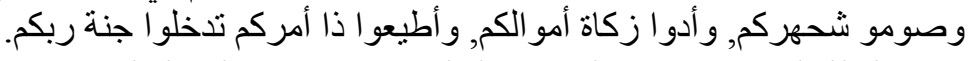

"Saya mendengar Abu Umamah berkata: Saya telah mendengar Rasulullah saw berkhutbah di haji wada', Beliau bersabda, Taqwalah kalian kepada Allah swt, shalatlah lima waktu, puasalah pada bulan ramadhan, tunaikanlah zakatmu, dan taatilah pemimpinmu, engkau akan masuk surga." 13

Dalam hadis lain juga disebutkan, Nabi bersabda:

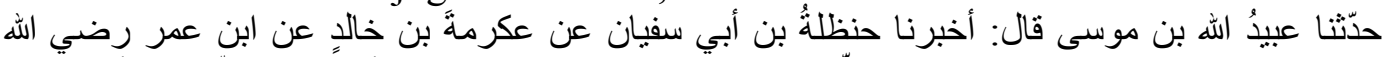

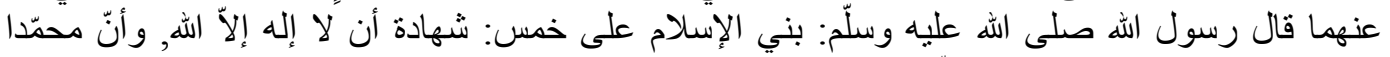

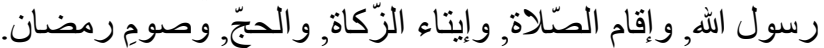

"Abdullah ibn Musa menceritakan kepada kami, dia berkata: Hanzhalah ibn Abi Sufyan memberitahukan kepada kami dari Ikrimah ibn Khalid dari ibn Umar r.a: Rasulullah saw telah bersabda: Islam didirikan atas lima perkara: persaksian bahwa tidak ada Tuhan kecuali Allah dan Muhammad utusan-Nya, mendirikan shalat, menunaikan zakat, haji dan puasa pada bulan ramadhan. "14

c. Ijtihad atau Ijma' Ulama

Sedangkan secara ijma', para ulama baik salaf (klasik) maupun khalaf (kontemporer) telah sepakat tentang adanya kewajiban zakat dan merupakan salah satu rukun Islam serta menghukumi kafir bagi yang mengingkari kewajibannya. ${ }^{15}$

\section{Sejarah Pengelolaan Zakat}

\section{a. Pengelolaan Zakat Masa Awal Islam}

Zakat sebagai salah satu tonggak perekonomian umat Islam sudah sejak awal mendapat perhatian. Hal ini perlu diketahui agar kita lebih menyadari bahwa ekonomi Islam sesungguhnya bukanlah konsep baru sama sekali apalagi utopia, melainkan sebuah

"Dan Dirikanlah shalat, tunaikanlah zakat dan ruku'lah beserta orang-orang yang ruku"'(an-Nisa: 43)

11

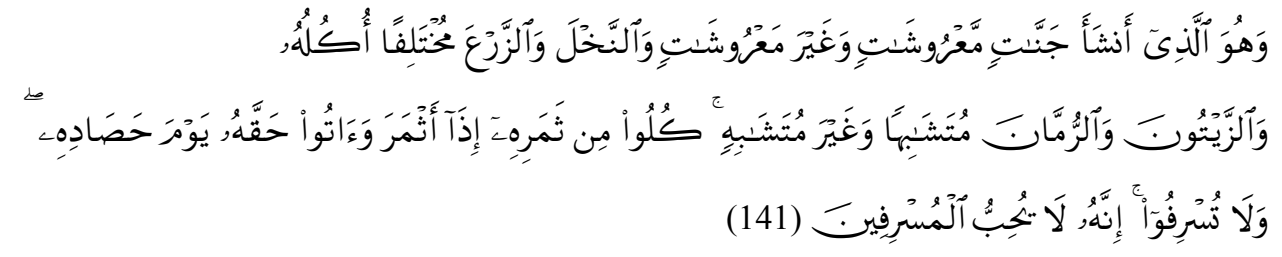

"Dan dialah yang menjadikan kebun-kebun yang berjunjung dan yang tidak berjunjung, pohon korma, tanam-tanaman yang bermacam-macam buahnya, zaitun dan delima yang serupa (bentuk dan warnanya) dan tidak sama (rasanya). makanlah dari buahnya (yang bermacam-macam itu) bila dia berbuah, dan tunaikanlah haknya di hari memetik hasilnya (dengan disedekahkan kepada fakir miskin); dan janganlah kamu berlebih-lebihan. Sesungguhnya Allah tidak menyukai orang yang berlebih-lebihan.” (al-An'am: 141)

${ }^{13}$ Fakhruddin, Fiqh dan Manajemen Zakat di Indonesia, hlm. 22.

${ }^{14}$ Ibid., hlm. 23.

${ }^{15}$ Ibid. 
konsep praktis yang prestasi dan kesuksesannya telah dicatat dengan baik menggunakan "tinta emas" dalam lembaran sejarah. Namun demikian, sebelumnya perlu ditandaskan bahwa keberhasilan ekonomi Islam itu tidak muncul secara kebetulan atau tanpa syarat, melainkan membutuhkan sebuah syarat mutlak. Ekonomi Islam hanya akan mungkin berhasil jika diterapkan dalam masyarakat Islam yang menerapkan Islam secara menyeluruh (kaffah), baik di bidang ekonomi itu sendiri maupun di bidang-bidang lainnya seperti politik, sosial, pendidikan, dan budaya. ${ }^{16}$

Sebab sistem kehidupan Islam itu bersifat integral dan saling melengkapi, Islam tidak menerima pemilah-milahan ajaran (parsial), di mana sebagian sistem Islam diamalkan dan sebagian lainnya dibuang ke "tong sampah" peradaban. Karena itu, jika ekonomi Islam diterapkan secara sepotong-sepotong dalam masyarakat yang menganut konsep ekonomi kapitalisme misalnya, maka ia tidak akan mungkin efektif. Allah Swt memerintahkan kita untuk menghormati persyaratan mutlak ini, yakni penerapan Islam secara komprehensif ( $k a f f a h$ ) sebagaimana firman-Nya dalam al-Baqarah: 208

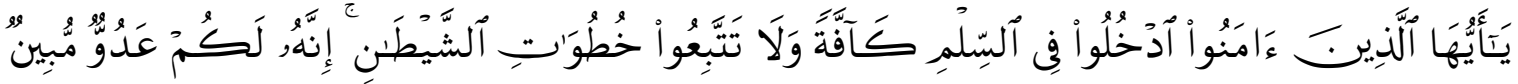

"Hai orang-orang yang beriman, masuklah kamu ke dalam Islam keseluruhan, dan janganlah kamu turut langkah-langkah syaitan. Sesungguhnya syaitan itu musuh yang nyata bagimu." 17

Zakat mulai disyariatkan pada tahun kedua Hijriyah, setelah terlebih dahulu disyariatkan puasa dan zakat fitrah. Dalam pengumpulan dan pengelolaan zakat, biasanya Nabi Muhammad saw mengumpulkan zakat perorangan dan membentuk panitia pengumpulan zakat dari umat Islam yang kaya (agniya), kemudian dibagikan kepada orang-orang yang miskin dan membutuhkan. Pelaksanaan zakat di zaman Rasulullah saw dan yang kemudian diteruskan oleh para sahabatnya, dilakukan dengan cara: para petugas mengambil zakat dari para muzakki, atau muzakki sendiri secara langsung menyerahkan zakatnya pada Bait al-Mal, lalu oleh para petugasnya (amil zakat) didistribusikan kepada para mustahiq yang tergabung dalam ashnaf tsamaniyah (delapan golongan orang yang berhak menerima zakat). ${ }^{18}$

Setelah Rasulullah saw wafat, maka tampuk kepemimpinan umat Islam berada di tangan para sahabatnya. Sahabat beliau yang pertama kali ditunjuk menjadi penggantinya untuk menangani urusan umat Islam adalah Abu Bakar al-Shiddiq. Ia melanjutkan apa yang telah dilakukan oleh Rasulullah saw dalam pembagian zakat di antara kaum muslimin yang berhak menerimanya. Beliau biasanya membagikan semua jenis harta kekayaan secara merata tanpa memperhatikan status masyarakat. Setelah Abu Bakar wafat, dilanjutkan lagi oleh Khalifah Umar bin Khathab, pada masa ini banyak negeri yang telah ditundukkannya, maka banyak harta yang masuk ke kas khalifah Islamiyah melalui lembaga Bait al-Mal. Karena banyaknya harta yang mengalir ke Madinah, maka tempat penyimpanan harta dengan mengangkat staf yang bekerja di bawah lembaga Bait al-Mal. Khalifah Umar bin Khathab sangat hati-hati dengan masalah pemasukan dan

\footnotetext{
${ }^{16}$ Ibid., hlm. 217.

${ }^{17}$ Departemen Agama RI, Al-Quran dan Terjemahnya, (Surabaya: Mahkota, 1989).

${ }^{18}$ Fakhruddin, Fiqh dan Manajemen Zakat di Indonesia, hlm. 218-221.
} 
pengeluaran keuangan Bait al-Mal, dan menyerahkannya kepada mereka yang berhak menerimanya. Al-Hasan r.a mengatakan bahwa sekali waktu Umar r.a menulis surat kepada Abu Musa al-Asy'ari, “ Ada satu hari dalam satu tahun yang mengaharuskan tidak satu dirham pun tertinggal atau tak terbagikan dari Bait al-Mal, kecuali dihabiskan seluruhnya sehingga Allah swt mengetahui setiap orang miskin mendapat haknya."19

Sedangkan pada masa khalifah Utsman, dalam pengaturan pengumpulan dan pembagian zakat dilakukan sesekali saja, dan berbagai jenis harta kekayaan disimpan di Bait al-Mal. Namun khalifah Utsman r.a membolehkan pembayaran zakat dengan barang-barang yang tidak nyata (bathin), seperti uang kontan, emas, dan perak. Kemudian barang-barang tersebut dibagikan oleh para pembayar zakat kepada yang membutuhkan. Sementara untuk barang-barang yang nyata (zhahir), seperti hasil pertanian, buah-buahan, dan ternak dibayarkan melalui Bait al-Mal. Dan ketika pada masa pemerintahan khalifah Ali bin Abi Thalib, kondisi Bait al-Mail ditempatkan kembali pada posisi yang sebelumnya. Ali, yang juga mendapat santunan dari Bait al-Mal seperti disebutkan oleh Ibnu Katsir, mendapatkan jatah pakaian yang hanya bisa menutupi tubuh sampai separo kakinya, dan sering bajunya itu penuh dengan tambalan. ${ }^{20}$

\section{b. Pengelolaan Zakat di Indonesia}

Sejarah Perkembangan dan lembaga hukum di Indonesia melalui proses yang panjang. Sejak Islam datang ke tanah air, zakat telah menjadi sumber dana pengembangan agama Islam. ${ }^{21}$ Praktek yang telah berlangsung ratusan tahun itu berjalan secara individual, langsung diberikan oleh muzaki kepada mustahik untuk keperluan konsumtif tanpa melalui amil zakat, dan jika pun melalui amil zakat hanya terbatas pada zakat fitrah. Berzakat melalui kelembagaan resmi, baru dikenal setelah adanya anjuran Presiden Soeharto untuk mengkoordinir pengelolaan zakat dengan membentuk Bazis DKI Jakarta pada tahun 1967. Semenjak saat tersebut pengelolaan zakat mulai dilaksanakan oleh lembaga yang bertugas mengumpulkan dan menyalurkan zakat. $^{22}$

Pengelolaan zakat sebelum tahun 90-an memiliki ciri khas antara lain yaitu, pada umumnya zakat diberikan langsung oleh muzaki kepada mustahik tanpa melalui amil zakat, jika pun melalui amil zakat hanya terbatas pada zakat fitrah, zakat yang diberikan umumnya hanya bersifat konsumtif untuk keperluan sesaat. ${ }^{23}$

Pada era reformasi tahun 1998, setelah menyusul runtuhnya kepemimpinan nasional Orde Baru, terjadi kemajuan luar biasa di bidang politik dan sosial kemasyarakatan. Setahun setelah reformasi tersebut, yakni 1999 terbitlah Undangundang No. 38 Tahun 1999 tentang Pengelolaan Zakat. Terwujudnya Undang-undang Pengelolaan Zakat di Indonesia merupakan catatan yang dikenang umat Islam selama periode Presiden B.J. Habibie. Dalam Undang-undang No. 38 Tahun 1999 dijelaskan prinsip pengelolaan zakat secara profesional dan bertanaggungjawab yang dilakukan oleh masyarakat bersama pemerintah. Pemerintah dalam hal ini berkewajiban

\footnotetext{
19 Ibid.

${ }^{20}$ Ibid.

${ }^{21}$ Muhammad, Hadi, Problematika Zakat dan Solusinya, (Yogyakarta: Pustaka Pelajar, 2010), hlm. 77.

${ }^{22}$ Hidayat Nur Wahid, Zakat \& Peran Negara, (Jakarta:FOZ, 2006), hlm. 124-125.

${ }^{23}$ Kuntaro Noor Aflah, Mohd. Nasir Tajang, Zakat dan Peran Negara, (Jakarta: Forum Zakat FOZ, 2006),
} hlm. 75 
memberikan perlindungan, pembinaan, dan pelayanan kepada muzakki, mustahiq, dan pengelola zakat. ${ }^{24}$

Dalam rangka melaksanakan pengelolaan zakat sesuai dengan amanat UndangUndang No. 38 Tahun 1999, pemerintah pada tahun 2001 membentuk Badan Amil Zakat Nasional (BAZNAS) dengan Keputusan Presiden. Di setiap daerah juga ditetapkan pembentukan Badan Amil Zakat Provinsi, Badan Amil Zakat Kabupaten/Kota hingga Badan Amil Zakat Kecamatan. Pemerintah juga mengukuhkan keberadaan Lembaga Amil Zakat (LAZ) yang didirikan oleh masyarakat. LAZ tersebut melakukan kegiatan pengelolaan zakat sama seperti yang dilakukan oleh Badan Amil Zakat. Pembentukan Badan Amil Zakat di tingkat nasional dan daerah menggantikan pengelolaan zakat oleh BAZIS (Badan Amil Zakat, Infaq, dan Shadaqah) yang sudah berjalan di hampir semua daerah. ${ }^{25}$

\section{Tinjauan Sosiologi Hukum Terhadap UU No. 23 Tahun 2011 Pasal 22}

Seorang sosiolog hukum Soerjono Soekanto berpendapat bahwa sosiologi hukum adalah suatu cabang ilmu pengetahuan yang secara analitis dan empiris mempelajari hubungan timbal balik antara hukum dengan gejala-gejala sosial lainnya. Maksudnya sejauh mana hukum itu mempengaruhi tingkah laku sosial dan pengaruh tingkah laku sosial terhadap pembentukan hukum. ${ }^{26}$

Hukum tidak harus dipahami sebagai suatu peraturan yang ada dalam kitab perundang-undangan atau kitab hukum lainnya. Akan tetapi, hukum juga perlu dilihat ke dalam konteks sosialnya, yaitu tempat di mana hukum itu berperan, dipergunakan serta diciptakan. Hukum diciptakan untuk mengatur pola hubungan tingkah laku manusia atau kelompok dalam proses interaksi antara satu dengan yang lainnya dalam masyarakat. Tidak ada satu masyarakat pun yang dapat hidup atau bertahan tanpa adanya hukum yang mengaturnya. Bagaimanapun dan bentuk apapun susunan masyarakatnya (baik masyarakat modern maupun sederhana, masyarakat urban maupun rural) hukum itu akan tetap ada. ${ }^{27}$

Sosiologi hukum membahas pengaruh timbal balik antara perubahan dan masyarakat. Perubahan hukum dapat mempengaruhi perubahan masyarakat, dan sebaliknya perubahan masyarakat dapat menyebabkan terjadinya perubahan hukum. ${ }^{28}$ Di Indonesia yang penduduknya mayoritas Muslim, hukum Islam menempati posisi yang paling tinggi di dalam masyarakat, meskipun istilah "hukum Islam" dalam masyarakat itu masih sebatas pengertian "fikih". Fikih bukanlah kandungan ajaran atau ilmu hukum Islam. Jadi, fikih sebenarnya adalah doktrin hukum Islam, atau lebih tepat dikatakan pendapat dan ajaran para Imam Mazhab. ${ }^{29}$

Zakat sebagai bagian dari ajaran Islam yang wajib ditunaikan oleh umat Islam terutama yang mampu (aghniya), tentunya sudah diterapkan dan ditunaikan oleh umat

${ }^{24}$ Ibid.

${ }^{25}$ Ibid.

${ }^{26}$ Sudirman Tebba, Sosiologi Hukum Islam, (Yogyakarta: UII Press Indonesia, 2003), hlm. 1.

${ }^{27}$ Bani Syarif Maulana, Sosiologi Hukum Islam di Indonesia, (Yogyakarta: Aditya Media Publishing, 2010), hlm. 1-2.

${ }^{28}$ Soerjono, Soekanto, Pengantar Sosiologi Hukum, (Jakarta: Bhatara Karya Aksara, 1997), hlm. 17

${ }^{29}$ M. Yahya Harahap, "Informasi Materi Kompilasi Hukum Islam: Mempositifkan Abstraksi Hukum Islam”, dalam. Cik Hasan Basri (ed.), Kompilasi Hukum Islam dalam Sistem Hukum Nasional, (Jakarta: Logos, 1991), hlm. 23. 
Islam Indonesia berbarengan dengan masuknya Islam ke Nusantara. Kemudian ketika Indonesia dikuasai oleh para penjajah, para tokoh agama Islam tetap melakukan mobilisasi pengumpulan zakat. Pada masa penjajahan Belanda pelaksanaan ajaran agama Islam (termasuk zakat) diatur dalam Ordonantie Pemerintah Hindia Belanda Nomor 6200 tanggal 28 Februari 1905. Dalam pengaturan ini pemerintah tidak mencampuri masalah pengelolaan zakat dan menyerahkan sepenuhnya kepada umat Islam dan bentuk pelaksanaannya sesuai dengan syariah Islam. ${ }^{30}$

Efektivitas lembaga yang mengelola zakat semacam BAZIS (Badan Amil Zakat, Infak dan Sedekah) sangat tergantung pada dukungan umat. Ada kesan selama ini bahwa umat lebih suka menyerahkan zakatnya secara langsung kepada mustahiq (orang yang berhak menerima) zakat dari pada memberikannya kepada badan zakat. Itu terjadi mungkin karena sewaktu zakat disyariatkan Islam masih berada pada tahap solidaritas mekanik, meminjam istilah Emile Durkheim , di mana hubungan sosial ditandai dengan hubungan antar individu yang kuat. Urusan sosial ditangani secara individu, dalam hal ini muzakki (wajib zakat) secara langsung menyerahkan zakatnya kepada mustahiq zakat. Namun setelah masyarakat mulai berkembang dan akan menjadi modern solidaritas mekanik berkurang dan muncul solidaritas organik, di mana urusan sosial mulai ditangani oleh lembaga yang khusus sebagai wujud pembagian kerja dalam masyarakat. Misalnya di bidang zakat ada lembaga yang khusus yang menangani yaitu BAZIS. ${ }^{31}$

Visi dan misi ini harus disosialisasikan kepada segenap pengurus agar menjadi pedoman dan arah dari setiap kebijakan atau keputusan yang diambil. Sehingga zakat yang dibentuk memiliki arah dan sasaran yang jelas. ${ }^{32}$

Tujuan besar dilaksanakannya pengelolaan zakat adalah:

a. Meningkatnya kesadaran masyarakat dalam penunaian dan dalam pelayanan ibadah zakat. Sebagaimana realitas yang ada di masyarakat bahwa sebagian besar umat Islam yang kaya (mampu) belum mampu menunaikan ibadah zakatnya, jelas ini bukan persoalan "kemampuan" akan tetapi adalah tentang "kesadaran ibadah zakat" yang kurang terutama dari umat Islam sendiri. Hal ini menyimpan pekerjaan rumah tersendiri bagaimana secara umum umat Islam meningkat kesadaran beragamanya.

b. Meningkatnya fungsi dan peranan pranata keagamaan dalam upaya mewujudkan kesejahteraan masyarakat dan keadilan sosial.

c. Meningkatnya hasil guna dan daya guna zakat. Setiap lembaga zakat sebaiknya memiliki database tentang muzakki dan mustahiq. Profil muzakki perlu didata untuk mengetahui potensi-potensi atau peluang untuk melakukan sosialisasi maupun pembinaan kepada muzakki adalah "nasabah" seumur hidup, maka perlu adanya perhatian dan pembinaan yang memadai guna memupuk nilai kepercayaannya. Terhadap mustahiq pun juga demikian, program pendistribusian dan pendayagunaan harus diarahkan sejauh mana mustahiq tersebut dapat meningkatkan kualitas kehidupannya, dari status mustahiq menjadi muzakki. ${ }^{33}$

\footnotetext{
${ }^{30}$ Fakhruddin, Fiqh \& Manajemen Zakat di Indonesia, hlm. 243-244.

${ }^{31}$ Sudirman Tebba, Sosiologi Hukum Islam, hlm. 40-41.

${ }^{32}$ Fakhruddin, Fiqh dan Manajemen Zakat di Indonesia, hlm. 251-252.

${ }^{33}$ Ibid., hlm. 253-254.
} 
Dalam setiap agama yang ada di Indonesia memang berlaku berbagai ketentuan berbeda terkait kewajiban keagamaan. Dalam agama Islam misalnya, ada kewajiban mengeluarkan zakat sebesar 2,5\%, dan dalam agama Kristen ada kewajiban pembayaran persepuluhan sebesar $10 \%$. Kewajiban mengeluarkan zakat ini didasarkan pada AlQuran surat $\mathrm{Al} \mathrm{Baqarah:} 267^{34}$, yang menentukan bahwa setiap pekerjaan yang halal yang mendatangkan penghasilan, setelah dihitung selama satu tahun hasilnya mencapai nisab (senilai 85 gram emas) maka wajib dikeluarkan zakatnya sebesar 2,5\%. Mengenai proses hingga zakat mengurangi pembayaran pajak (dalam hal ini pajak penghasilan), hal ini sudah diatur sejak adanya UU No. 38 Tahun 1999 tentang Pengelolaan Zakat, dan kemudian lebih dipertegas oleh UU Zakat yang terbaru yang menggantikan UU 38/1999 yaitu UU No. 23 Tahun 2011 tentang Pengelolaan Zakat. Latar belakang dari pengurangan ini dijelaskan dalam penjelasan Pasal 14 ayat (3) UU 38/1999 bahwa pengurangan zakat dari laba/pendapatan sisa kena pajak adalah dimaksudkan agar wajib pajak tidak terkena beban ganda, yakni kewajiban membayar zakat dan pajak. Ketentuan ini masih diatur dalam UU yang terbaru yakni dalam Pasal 22 UU 23/2011: "Zakat yang dibayarkan oleh muzaki kepada BAZNAS atau LAZ dikurangkan dari penghasilan kena pajak.". ${ }^{35}$

Jadi, pemberian zakat memang dapat mengurangi pajak, karena zakat dikecualikan dari objek pajak. Pengurangan pajak ini juga berlaku atas sumbangan wajib keagamaan bagi pemeluk agama lain yang diakui di Indonesia, yang diterima oleh lembaga keagamaan yang dibentuk atau disahkan oleh pemerintah dan yang diterima oleh penerima sumbangan yang berhak, yang ketentuannya diatur dengan atau berdasarkan Peraturan Pemerintah. Dan peraturan perundang-undangan yang telah disebutkan di atas telah berlaku efektif di Indonesia, demikian pula dengan mekanisme yang telah diaturnya.

Zakat pada hakikatnya adalah bagian tertentu yang ada pada harta orang Islam yang wajib dikeluarkan atas perintah Allah untuk kepentingan orang lain menurut kadar yang ditentukan-Nya. Zakat memperbaiki perasaan-perasaan yang buruk yang timbul di antara orang-orang kaya dan miskin, dan memperbaiki hubungan antara mereka yang mengeluarkan zakat dengan kelompok yang menerima zakat. ${ }^{36}$ Sedangkan pajak pada hakikatnya adalah kewajiban material seorang warga pada negaranya untuk dibayar

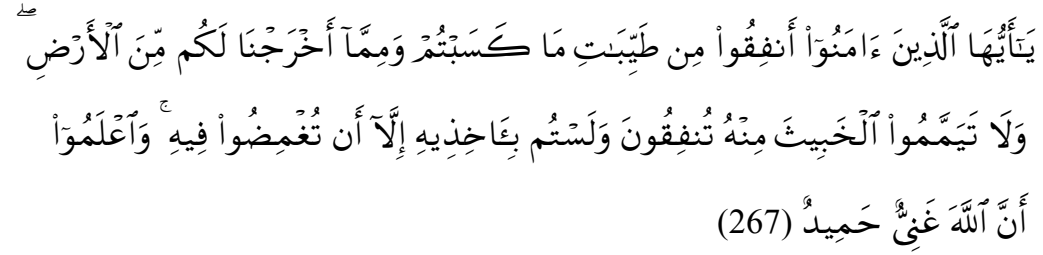

" Hai orang-orang yang beriman, nafkahkanlah (di jalan Allah) sebagian dari hasil usahamu yang baik-baik dan sebagian dari apa yang kami keluarkan dari bumi untuk kamu. dan janganlah kamu memilih yang buruk-buruk lalu kamu menafkahkan daripadanya, padahal kamu sendiri tidak mau mengambilnya melainkan dengan memincingkan mata terhadapnya. dan Ketahuilah, bahwa Allah Maha Kaya lagi Maha Terpuji."(Q.S. al-Baqarah: 267).

${ }^{35}$ Dasar Hukum dan Mekanisme Zakat Sebagai Pengurang Pajak - hukumonline.com.htm

${ }^{36}$ Abdul, Al-Hamid Mahmud Al-Ba'ly, Ekonomi Zakat: Sebuah Kajian Moneter Keuangan Syariah, (Jakarta: PT Raja Grafindo Persada, 2006), hlm. 134 
menurut ukuran yang telah ditentukan mengenai kekayaan pribadi seseorang, dan dipergunakan untuk membiayai pengeluaran-pengeluaran negara. Dengan demikian zakat dan pajak mempunyai persamaan dan perbedaan. Persamaannya terlihat antara lain pada pembebanan kewajiban itu atas harta kekayaan yang dimiliki seseorang dan pada pribadi orang yang bersangkutan. Perbedaannya antara lain:

a. Zakat adalah kewajiban agama yang ditetapkan Alah, sedangkan pajak adalah kewajiban warga Negara yang ditentukan oleh pemerintah.

b. Yang wajib mengeluarkan zakat adalah orang-orang Islam, sedangkan yang wajib membayar pajak tidak hanya orang Islam tetapi semua warga Negara Indonesia dan warga Negara Asing tanpa memandang agama yang dipeluknya.

c. Yang berhak menerima zakat sudah tentu kelompoknya, sedangkan yang berhak menikmati pajak adalah semua penduduk yang ada dalam satu negara.

d. Sanksi tidak membayar zakat adalah dosa, sedangkan sanksi tidak membayar pajak adalah denda atau hukuman saja.

e. Zakat tidak mungkin dihapuskan karena merupakan rukun Islam ketiga, sedangkan pajak mungkin saja diganti atau dihapuskan tergantung kebijakan negara. ${ }^{37}$

Dari uraian itu jelaslah perbedaan zakat dengan pajak, karena itu dalam Islam, tidaklah mungkin menggantikan kedudukan zakat dengan pajak. Yang mungkin adalah memadukannya, antara lain dengan memotong jumlah pajak dengan jumlah zakat yang telah dibayar oleh seseorang.

Rendahnya jumlah zakat yang dikumpulkan oleh lembaga zakat disebabkan oleh banyaknya orang Islam yang langsung memberikan zakatnya kepada mustahiknya. Karena itu masalah mendesak yang perlu dilakukan sekarang antara lain adalah meningkatkan apresiasi umat terhadap lembaga pengumpul zakat. Apresiasi umat Islam terhadap zakat kelihatannya masih rendah, mungkin karena khawatir zakatnya tidak sampai kepada mustahiknya. ${ }^{38}$

Pemberlakuan zakat penghasilan sebagai pengurang penghasilan kena pajak jelas akan berpengaruh langsung terhadap penerimaan pemerintah dari sektor pajak. Semakin banyak umat Islam yang membayar zakat akan mengakibatkan semakin banyaknya pengurang penghasilan kena pajak. Sehingga apabila penghasilan kena pajak menjadi kecil dengan sendirinya pajak penghasilan yang diterima negara juga mengecil. Padahal saat ini pemerintah justru sedang berupaya memaksimalkan penerimaannya dari sektor pajak. Teteapi bila mau dikaji lebih lanjut, dapat dibuktikan bahwa efek zakat sebagai pengurang penghasilan kena pajak adalah positif terhadap pendapatan nasional, sekalipun zakat penghasilan mengurangi penerimaan negara dari sektor pajak, tapi kondisi perekonomian secara makro tetap membaik. Bahkan pendapatan nasional

\footnotetext{
37 Ibid

${ }^{38}$ Sudirman, Tebba, Sosiologi Hukum Islam, hlm. 41
} 
dengan variable zakat lebih tinggi hasilnya dibandingkan pendapatan nasional tanpa variable zakat. ${ }^{39}$

Dalam UU No. 23 tahun 2011, yang merupakan pembaharuan dari Undang-Undang No. 38 tahun 1999, untuk membantu BAZNAS dalam pelaksanaan pengumpulan, pendistribusian, dan pendayagunaan zakat di masyarakat dapat dibentuk Lembaga Amil Zakat yang disingkat menjadi LAZ. Pembentukan LAZ wajib mendapat izin Menteri atau pejabat yang ditunjuk oleh Menteri. Dalam rangka pengumpulan zakat, muzakki melakukan penghitungan sendiri atas kewajiban zakatnya. Dalam hal tidak dapat menghitung sendiri kewajiban zakatnya, muzakki dapat meminta bantuan BAZNAS. Zakat yang dibayarkan oleh muzakki kepada BAZNAS atau LAZ dikurangkan dari penghasilan kena pajak. BAZNAS atau LAZ wajib memberikan bukti setoran zakat kepada setiap muzakki. Bukti setoran zakat digunakan sebagai pengurang penghasilan kena pajak. Pendistribusian zakat dilakukan berdasarkan skala prioritas dengan memperhatikan pemerataan, keadilan, dan kewilayahan. ${ }^{40}$

Masalah kemiskinan, idealnya merupakan tanggung jawab negara. Namun melihat kondisi negara yang demikian terpuruk, setidaknya dana zakat dengan potensi yang begitu besar semestinya dapat dioptimalkan manfaatnya. ${ }^{41}$ Keberadaan UU tentang Pengelolaan Zakat yang baru sebagai pengganti UU No. 38 Tahun 1999 tentang Pengelolaan Zakat diharapkan dapat meningkatkan efektivitas dan efesiensi pelayanan dalam pengelolaan zakat dan meningkatkan manfaat zakat untuk mewujudkan kesejahteraan masyarakat dan menanggulangi kemiskinan. Titik tekan pendistribusian dan pendayagunaan zakat harus diarahkan untuk menangani kemiskinan demi mewujudkan kesejahteraan mustahik. Sebab seperti dimaklumi, hingga kini jumlah orang miskin di Indonesia masih cukup besar meskipun pada setiap tahun terus mengalami penurunan. Menurut Data BPS 2018 menunjukkan bahwa persentase kemiskinan Indonesia akhir tahun 2017 sebesar 10,12\% atau sekitar 26,58 juta jiwa. Pada akhir 2017, Gini ratio Indonesia pada akhir tahun 2017 sebesar 0,415 (BPS, 2018). Hal ini berarti bahwa 1\% penduduk Indonesia menguasai $41,5 \%$ aset nasional. Dengan kata lain, pertumbuhan ekonomi yang terjadi tidak terdistribusi secara merata di Indonesia. Oleh karena itu, institusi zakat dalam perekonomian di Indonesia diharapkan dapat menjadi faktor stimulus kemakmuran ekonomi Indonesia dalam membantu mengurangi tingkat kemiskinan, menciptakan keadilan ekonomi, menciptakan distribusi pendapatan yang merata, dan menjadi jaminan sosial dengan pelayanan yang efektif.$^{42}$ Zakat boleh didayagunakan untuk usaha produktif dalam rangka penanganan fakir miskin dan peningkatan kualitas umat. Namun demikian, pendayagunaan zakat untuk usaha produktif itu hanya dilakukan apabila kebutuhan dasar mustahik telah terpenuhi.

${ }^{39}$ Safarni, Husain, Risalah Hukum: Zakat Penghasilan sebagai Pengurang Penghasilan Kena Pajak: Income Zakat as The Reducer of Taxable Income, Vol. 6, No. 1 (Samarinda: FH Universitas Mulawarman, 2010), hlm. 20

40 A. Muchaddam, Fahham, Paradigma Baru Pengelolaan Zakat di Indonesia, Vol.III, No. 19/I/P3DI/Oktober/2011, hlm. 11

${ }^{41}$ Umrotul, Khasanah, Manajemen Zakat Modern: Instrumen Pemberdayaan Ekonomi Umat, (Malang: tt, 2010), hlm 76

${ }^{42}$ Muhammad Widyan Rahman. https://www.validnews.id/POTENSI-ZAKAT-INDONESIA-Gbg, diakses tanggal 13 Juni 2018. 
Berdasarkan Undang-undang No. 23 tahun 2011 tentang pengelolaan zakat atas perubahan UU sebelumnya yaitu Undang-undang No. 38 tahun 1999 yang lebih spesipiknya tertuang dalam pasal 14 ayat (3) dan dipertegas lagi maknaya pada pasal 22 UU No. 23 tahun 2011 yang berisi tentang bahwa, "Zakat yang dibayarkan oleh muzaki kepada BAZNAS atau LAZ dikurangkan dari penghasilan kena pajak". Hal ini dilakukan untuk tidak terjadi pembebanan ganda yakni dalam hal zakat dan pajak. Pasal ini merupakan bentuk penegasan terhadap undang-undang sebagai alat hukum negara terhadap hukum Islam yang berada dan berkembang dalam suatu masyarakat. Sebagai konsekuensi logis yang diambil negara terhadap pengelolaan zakat tersebut. Bahwa zakat adalah merupakan rukun Islam yang ketiga yang harus ditunaikan oleh seorang muslim yang mampu dalam menyisihkan atau mensedekahkan sebagian hartanya untuk berbagi kepada orang miskin yang merupakan hak mereka untuk diberi kemaslahatan. Karena harta itu merupakan titipan Illahi yang Allah berikan atau cukupkan kepada hambanya yang mempunyai harta berlebih untuk bisa berbagi dengan orang-orang fakir miskin, yang mana sudah Allah tuliskan dalam al-Qur'an maupun melalui sunnah Nabi. Hal ini dimulai dari kesadaran yang tinggi terhadap muzakki sendiri dalam berzakat kepada mustahiq, yang zakatnya itu diserahkan kepada pengurus BAZNAS atau LAS dalam mengumpulkannya, mengelolanya dalam mendistribusikannya serta mendayagunakan zakat tersebut secara optimal demi kesejahteraan rakyatnya khususnya dalam bidang ekonomi masyarakat agar kiranya dapat meminilir angka kemiskinan yang terjadi pada masyarakat Indonesia.

Namun di luar itu semua upaya pemerintah sudah cukup bagus dalam sistem pengelolaan zakat untuk memperbaiki perekonomian rakyatnya. Tetapi pemerintah perlu lebih giat lagi dalam mensosialisasikan kepada masyarakatnya untuk memberikan sebuah pemahaman terhadap mereka yang mempunyai harta berlebih agar bisa mengeluarkan zakatnya. Bahwa zakat itu merupakan kewajiban sebagai seorang Muslim yang harus disisihkan kepada mereka yang sangat membutuhkan bantuan. Dan zakat juga memiliki potensi yang sangat besar dalam memperbaiki dan memakmurkan kemaslahatan rakyat.

\section{Tinjauan Ushul Fikih Terhadap Pengelolaan Zakat}

Maqasid Syari'ah berarti tujuan Allah dan Rasul-Nya dalam merumuskan hukumhukum Islam. Tujuan itu dapat ditelusuri dalam ayat-ayat al-Qur'an dan Sunnah Rasulullah sebagai alasan logis bagi rumusan suatu hukum yang berorientasi kepada kemaslahatan umat manusia.

Abu Ishaq al-Syatibi melaporkan hasil penelitian para ulama terhadap ayat-ayat alQur'an dan Sunnah Rasulullah bahwa hukum-hukum disyariatkan Allah untuk mewujudkan kemaslahatan umat manusia, baik di dunia maupun di akhirat kelak. Kemaslahatan yang akan diwujudkan itu menurut asy-Syatibi terbagi kepada tiga tingkatan, yaitu kebutuhan dharuriyat, ${ }^{43}$ kebutuhan hajiyat, ${ }^{44}$ dan kebutuhan tahsiniyat. ${ }^{45}$

${ }^{43}$ Dharuriyat adalah tingkat kebutuhan yang harus ada atau disebut dengan kebutuhan primer. Bila tingkat kebutuhan ini tidak terpenuhi, akan terancam keselamatan umat manusia baik di dunia maupun di akhirat kelak. Lihat Satria Effendi dan M. Zein, Ushul Fiqh, (Jakarta: Kencana, 2009), hlm. 234.

44 Hajiyat adalah kebutuhan-kebutuhan sekunder, di mana bilamana tidak terwujudkan tidak sampai mengancam keselamatanyya, namun akan mengalami kesulitan. Syariat Islam menghilangkan segala kesulitan itu. Adanya hukum rukhsah (keringanan) seperti dijelaskan Abd al-Wahhab Khallaf, adalah sebagai contoh dari kepedulian Syariat Islam terhadap kebutuhan ini. ibid., hlm. 235. 
Perubahan dalam hukum Islam merupakan hal yang wajar. Sebagai hasil ijtihad manusia, fiqh ternyata tidak lepas dari dialektika antara idealis dan realitas, antara ideologi dan empiris, sehingga kebenarannya tidaklah bersifat absolut namun bersifat relatif sesuai dengan relatifitas konstruksi pemikiran manusia yang tidak bisa lepas dari ruang dan waktu. ${ }^{46}$ Dengan demikian, aturan hukum Islam khususnya fikih yang selama ini ada dapat diubah dengan melakukan reinterpretasi dan mereformulasikannya agar selaras dengn perkembangan dan tuntutan zaman, namun tetap berpijak pada prinsip-prinsip syariat Islam. Hal ini sesuai dengan kaidah usul al-fikih yang berbunyi:

$$
\text { تغير الفتوى بتغيّر الأزمان و الأمكانة والأحوال و العو ائد }
$$

Dalam sistem perundangan yang berlaku di Indonesia mengenai pengelolaan zakat, secara jelas telah dideskripsikan bahwa pengelolaan zakat yang telah ditetapkan pemerintah harus betul-betul mewujudkan keadilan sosial. Sehingga, tolak ukur keberhasilan pengelolaan zakat bisa dilihat dari perkembangan dan pertumbuhan ekonomi (kesejahteraan mustahiq), hal ini membuktikan peran distribusi zakat sangat menentukan dalam keberhasilan pengelolaan zakat.

Perbedaan sosio-ekonomi yang berbeda di setiap wilayah memungkinkan berubahnya jalur pendistribusian zakat, sebagian ulama mengharuskan bahwa pendistribusian zakat berdasarkan lokalitas dan yang menjadi prioritas utama adalah mustahiq yang berada diwilayah muzakki. Realitas di Indonesia membuktikan bahwa pendapat ulama yang mengharuskan melakukan distribusi lokal ternyata tidak relevan, karena banyaknya jumlah mustahiq yang tersebar di berbagai wilayah. Maka pertimbangan yang diutamakan adalah kemaslahatan dan keadilan sosial. dalam hal ini kerangka analisis maslahat mursalah akan diterapkan mengingat keterikatan antara pemerintah (ulil amri) dan masyarakat (kepentingan orang banyak).

Maslahat Mursalah adalah suatu kaidah istinbath hukum yang berarti suatu kemaslahatan yang tidak ditetapkan oleh syara' suatu hukum untuk mewujudkannya dan tidak pula terdapat suatu dalil syara' yang memerintahkan untuk memperhatikan atau mengabaikannya. ${ }^{48}$ Setidaknya ada tiga syarat yang harus dipenuhi ketika menjadikan maslahat mursalah sebagai hujjah, yaitu; 1). Maslahat tersebut haruslah maslahat haqiqi (sejati) bukan berdasarkan perkiraan (wahm) belaka, artinya kemaslahatan itu dapat membawa kemanfaatan dan menolak kemudharatan, 2). Kemaslahatan itu adalah kemaslahatan umum yang menyangkut kepentingan orang banyak, bukan untuk perseorangan, 3). Kemaslahatan itu tidak bertentangan dengan dasar-dasar yang telah digariskan nas dan ijma. ${ }^{49}$

${ }^{45}$ Tahsiniyat ialah tingkat kebutuhan yang apabila tidak terpenuhi tidak mengancam eksistensi salah satu dari lima pokok di atas dan tidak pula menimbulkan kesulitan. Tingkat kebutuhan ini berupa kebutuhan pelengkap, seperti dikemukakan asy-Syatibi, hal-hal yang merupakan kepatutan menurut adat-istiadat, menghindarkan hal-hal yang tidak enak dipandang mata, dan berhias dengan keindahan yang sesuai dengan tuntutan norma dan akhlak. Ibid., hlm. 236.

${ }^{46}$ Ashgar Ali Engineer, Hak-hak Perempuan dalam Islam, alih bahasa Farid Wajidi dan Cici Farkha Asseqaf, cet. I (Yogyakarta: LSPPA, 2000), hlm. 18.

${ }^{47}$ Fathurrahman Djamil, Filsafat Hukum Islam, (Jakarta: Logos, 1999), hlm. 164.

${ }^{48}$ Abd al-Wahab Khallaf, 'Ilmu Usul al-Fiqh, cet. VIII, (ttp :Dar al-Ilm, 1398 H/1978 M), hlm. 84.

${ }^{49}$ Adapun maslahat tersebut hendaknya meliputi lima (5) jaminan dasar yaitu: 1. Kemaslahatan keyakinan agama (hifz ad-Din), 2. Kemaslahatan jiwa (hifz an-Nafs), 3. Kemaslahatan akal (hifz al-'Aql), 4. Kemaslahatan keturunan (hifz an-Nasab), 5. Keselamatan harta (hifz al-Mal). Lihat Abd al-Wahab Khallaf, Ilmu Usul al-Fiqh, hlm. $86-87$. 
Prinsip tersebut merupakan salah satu upaya penetapan hukum yang didasarkan pada pertimbangan kebaikan dan kesejahteraan, manfaat dan kemakmuran umat demi kepentingan dan kemaslahatan rakyat banyak yang mana harus mempertimbangkan situasi dan kondisi kemaslahatan umat yang menguntungkan, karena bagaimanapun juga hukum itu mengikuti kemaslahatan yang lebih besar, dan kemaslahatan besar itu lebih diutamakan daripada kemaslahatan yang lebih kecil bentuknya. Hal ini senada dengan apa yang dikatakan Yusuf al-Qaradawi:

Dalam kaidah ushul fikih umum dikenal:

$$
\text { تقدّم المصلحة الكبيرة على المصلعة الصغيرة }
$$$$
\text { تصرّف الإمام على الرّعية منوط بالمصلحة }
$$

"Kebijakan seorang pemimpin terhadap rakyatnya bergantung kepada kemaslahatn"

Prinsipnya bahwa setiap kebijakan pemerintah (imam) yang berkaitan dengan kepentingan umum harus ditempatkan sebagai kebijakan yang berorientasi berdasarkan maslahat dan keadilan sosial dengan melihat fenomena yang ada dalam suatu masyarakat demi terciptanya kemakmuran rakyatnya.

Memperkuat kaidah ini, apa yang dikatakan oleh Umar bin Khattab yang diriwayatkan oleh Said bin Mansur:

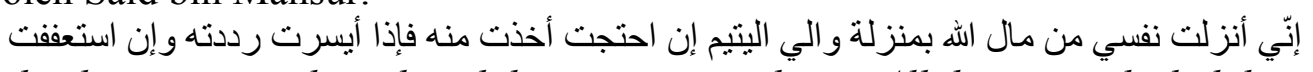

"Sungguh aku menempatkan diri dalam mengurus harta Allah seperti kedudukan seorang wali anak yatim, jika aku membutuhkan aku mengambil daripadanya, jika aku dalam kemudahan aku mengembalikannya, dan jika aku berkecukupan aku menjauhinya",52

Kaidah ini menegaskan bahwa seorang pemimpin harus berorientasi kepada kemaslahatan rakyat, bukan mengikuti keinginan hawa nafsunya atau keinginan keluarganya atau kelompoknya. Kaidah ini juga dikuatkan oleh surat an-Nisa ayat: 58.

Banyak contoh yang berhubungan dengan kaidah tersebut yaitu setiap kebijakan yang maslahat dan manfaat bagi rakyat maka itulah yang harus direncanakan, dilaksanakan, diorganisasikan, dan dinilai/dievaluasi kemajuannya. Sebaliknya, kebijakan yang mendatangkan mafsadah dan memudaratkan rakyat, itulah yang harus disingkirkan dan dijauhi. Dalam upaya-upaya pembangunan misalnya, membangun perekonomian rakyat dengan diadakannya lembaga-lembaga zakat baik melalui BAZNAS atau LAZ itu sendiri, sehingga pertumbuhan ekonomi rakyat bisa maju dengan pesat dan berkembang demi tercipatnya suasana yang kondusif bagi keuangan ekonomi dan kesejahteraan rakyatnya. Dan di sini lah kemaslahatan yang sebenarnya untuk kepentingan bersama dengan rakyatnya.

Terkait dengan hal ini, Mahkamah Konstitusi akhirnya menggelar sidang pengucapan putusan atas tuntutan pengujian ulang UU No. 23 tahun 2011 tentang pengelolaan zakat atau UUPZ (31/10). Tuntutan judicial review tersebut dimohonkan oleh beberapa organisasi pengelola zakat seperti Yayasan Dompet Dhuafa, Yayasan Rumah Zakat Indonesia, Yayasan Yatim Mandiri dan organisasi lainnya. Dari beberapa pasal yang

50 Yusuf Qaradawi, Fikih Priotitas Urutan Amal Yang Terpenting Dari Yang Penting, alih bahasa Muh. Nur Hakim, Cet. I, (Jakarta: Gema Insani Press, 1996), hlm. 36.

${ }^{51}$ Jalal ad-Din Abd ar-Rahman Ibn Abi Bakar as-Suyutiy, al-Asybah wa an-Nazair, (Semarang: Maktabah Usaha Keluarga, t.t), hlm. 184.

52 A. Djazuli, Kaidah-Kaidah Fikih: Kaidah-Kaidah Hukum Islam Dalam Menyelesaikan MasalahMasalah Yang Praktis, (Jakarta: Kencana, 2006), hlm. 147-148 
dimohonkan untuk diuji, sebagian dikabulkan oleh hakim. ${ }^{53}$ Alhamdulillah, BAZNAS menyambut baik Putusan Mahkamah Konstitusi atas Judicial Review Undang-Undang Nomor 23 Tahun 2011 tentang Pengelolaan Zakat yang dibacakan dalam sidang. Ketua Umum BAZNAS Prof. Dr. KH Didin Hafiduddin mengatakan, BAZNAS menyampaikan terima kasih kepada negara dan rakyat Indonesia, melalui Keputusan Mahkamah Konstitusi telah menyelesaikan judicial review ini. "Tak ada kalah dan menang, semua adalah amanah yang harus dijalankan dengan sebaik-baiknya. Insya Allah putusan ini semakin memperkuat optimalisasi penghimpunan dan penyaluran zakat secara nasional dalam mewujudkan kesejahteraan masyarakat sebagai bagian dari tujuan pengelolaan zakat." Artinya putusan yang dikeluarkan Mahkamah konstitusi itu sudah cukup mewakili kemaslahatan bersama dalam mensejahterakan masyarakat kedepannya agar menjadi lebih baik lagi keuangan perekonomiannya dalam memberantas kemiskinan rakyat Indonesia.

\section{Kesimpulan}

Tinjauan sosiologi hukum dalam proses yang melatarbelakangi kronologis hingga zakat mengurangi pembayaran pajak (dalam hal ini pajak penghasilan), hal ini sudah diatur sejak adanya UU No. 38 Tahun 1999 tentang Pengelolaan Zakat, dan kemudian lebih dipertegas oleh UU Zakat yang terbaru yang menggantikan UU 38/1999 yaitu UU No. 23 Tahun 2011 tentang Pengelolaan Zakat. Latar belakang dari pengurangan ini dijelaskan dalam penjelasan Pasal 14 ayat (3) UU 38/1999 bahwa pengurangan zakat dari laba/pendapatan sisa kena pajak adalah dimaksudkan agar wajib pajak tidak terkena beban ganda, yakni kewajiban membayar zakat dan pajak. Dalam tataran implementasinya zakat sebagai pengurang pajak dapat mengurangi pendapatan sektor pajak, tetapi kalau dikaji lebih dalam dapat memberikan energi yang positif bagi pendapatan nasional. Dalam Islam, tidaklah mungkin menggantikan kedudukan zakat dengan pajak. Yang mungkin adalah memadukannya, antara lain dengan memotong jumlah pajak dengan jumlah zakat yang telah dibayar oleh seseorang. Untuk mereka yang wajib menunaikan zakat dan sekaligus menjadi wajib pajak, cara ini mungkin akan dapat diterima Karena menurut keyakinan mereka kewajiban agama telah mereka penuhi bersamaan dengan pemenuhan kewajibannya terhadap Negara.

Adapun dalam tinjauan ushul fikihnya terkait dengan Undang-Undang No. 23 Tahun 2011 sebagai perubahan dari sebelumnya yaitu Undang-Undang No. 38 Tahun 1999 tentang Pengelolaan Zakat. Bahwa pemerintah di sini sudah melakukan upaya-upaya pembaruan dalam mengatur masalah UU zakat tersebut demi memakmurkan kesejahteraan masyarakatnya, dan ini sudah cukup mewakili maksud dari maqasid asy-Syariah itu sendiri dalam mencapai tujuan kemaslahatan baik di dunia maupun kemaslahatan di akhirat, karena dengan adanya UU ini maka pengelolaan zakat bisa dioptimalisasikan dengan baik dengan melalui lembaga-lembaga yang telah pemerintah amanahkan kepada lembaga yang terkait yang sesuai dengan apa yang dipositifkan dalam Undang-undang zakat untuk menjaga kemaslahatan rakyatnya.

\section{DAFTAR PUSTAKA}

Abd al-Wahab, Khallaf, 'Ilmu Usul al-Fiqh, cet. VIII, ttp :Dar al-Ilm, 1398 H/1978 M.

\footnotetext{
53 http://pusat.baznas.go.id/berita-utama/baznas-ajak-seluruh-opz-laksanakan-putusan-mk-tentang-uuzakat/ di akses tanggal, 17/12/2013.
} 
Al-Hamid Mahmud Al-Ba'ly, Abdul, Ekonomi Zakat: Sebuah Kajian Moneter Keuangan Syariah, Jakarta: PT Raja Grafindo Persada, 2006

al-Qardhawi, Yusuf, Fiqh al-Zakah, Muassasah al-Risalah, Beirut: Dar al-Fikr, t.t.,

al-Sheiekh, Abdallah dalam John E. Efosito, Ensiklopedi Dunia Islam Modern, Jilid 6, Jakarta: Mizan, 2001

Ashgar Ali, Engineer, Hak-hak Perempuan dalam Islam, alih bahasa Farid Wajidi dan Cici Farkha Asseqaf, cet. I Yogyakarta: LSPPA, 2000.

As-Suyutiy, Jalal ad-Din Abd ar-Rahman Ibn Abi Bakar. al-Asybah wa an-Nazair, Semarang: Maktabah Usaha Keluarga, t.t.

Dasar Hukum dan Mekanisme Zakat Sebagai Pengurang Pajak - hukumonline.com.htm

Departemen Agama RI, Al-Quran dan Terjemahnya. Surabaya: Mahkota, 1989.

Djazuli, A. Kaidah-Kaidah Fikih: Kaidah-Kaidah Hukum Islam Dalam Menyelesaikan MasalahMasalah Yang Praktis, Jakarta: Kencana, 2006

Effendi, Satria dan M. Zein, Ushul Fiqh, Jakarta: Kencana, 2009,

Fahham, A. Muchaddam, Paradigma Baru Pengelolaan Zakat di Indonesia, Vol.III, No. 19/I/P3DI/Oktober/2011

Fakhruddin, Fiqh \& Manajemen Zakat di Indonesia, UIN-Malang Press: 2008

Fathurrahman, Djamil, Filsafat Hukum Islam, Jakarta: Logos, 1999,

Ghofur Anshori, Abdul, dan Yulkarnain Harahab, Hukum Islam Dinamika dan Perkembangannya di Indonesia, Yogyakarta: Kreasi Total Media, 2008

Hadi, Muhammad, Problematika Zakat dan Solusinya, Yogyakarta: Pustaka Pelajar, 2010

Harahap, M. Yahya ."Informasi Materi Kompilasi Hukum Islam: Mempositifkan Abstraksi Hukum Islam”, dalam. Cik Hasan Basri ed., Kompilasi Hukum Islam dalam Sistem Hukum Nasional, Jakarta: Logos, 1991

http://pusat.baznas.go.id/berita-utama/baznas-ajak-seluruh-opz-laksanakan-putusan-mk-tentanguu-zakat/ di akses tanggal, 17/12/2013.

Husain, Safarni, Risalah Hukum: Zakat Penghasilan sebagai Pengurang Penghasilan Kena Pajak: Income Zakat as The Reducer of Taxable Income, Vol. 6, No. 1 Samarinda: FH Universitas Mulawarman, 2010

Khasanah, Umrotul, Manajemen Zakat Modern: Instrumen Pemberdayaan Ekonomi Umat, Malang: tt, 2010 
Kuntaro Noor Aflah, Mohd. Nasir Tajang, Zakat dan Peran Negara, Jakarta: Forum Zakat FOZ, 2006

Maulana, Bani Syarif . Sosiologi Hukum Islam di Indonesia, Yogyakarta: Aditya Media Publishing, 2010.

Mohammad Daud, Ali, Sistem Ekonomi Islam: Zakat dan Wakaf, Jakarta: UI-Press, 2006

Mursyid, Mekanisme Pengumpulan Zakat, Infaq dan Shadaqah; Menurut Hukum Syara' dan Undang-undang, Yogyakarta: Magistra Insania Press, 2006

Nawawi, Ismail, Zakat dalam Perspektif Fiqh, Sosial \& Ekonomi, Surabaya: CV. Putra Media Nusantara, 2010

Nur Wahid, Hidayat, Zakat \& Peran Negara, Jakarta:FOZ, 2006

Qaradawi, Yusuf. Fikih Priotitas Urutan Amal Yang Terpenting Dari Yang Penting, alih bahasa Muh. Nur Hakim, Cet. I, Jakarta: Gema Insani Press, 1996.

Safarni, Husain, Risalah Hukum: Zakat Penghasilan sebagai Pengurang Penghasilan Kena Pajak: Income Zakat as The Reducer of Taxable Income, Vol. 6, No. 1 Samarinda: FH Universitas Mulawarman, 2010

Soekanto, Soerjono, Pengantar Sosiologi Hukum, Jakarta: Bhatara Karya Aksara, 1997.

Soekanto, Soerjono dan Sri Mamudji, Penelitian Hukum Normatif, Jakarta: Raja Grafindo Persada, 2003.

Tebba, Sudirman, Sosiologi Hukum Islam, Yogyakarta: UII Press Indonesia, 2003

Undang-Undang No. 23 Tahun 2011 Tentang Pengelolaan Zakat.

Undang-Undang No. 38 Tahun 1999 Tentang Pengelolaan Zakat. 